\title{
ENVISIONING LIVEABILITY AND DO-IT-TOGETHER URBAN DEVELOPMENT
}

\author{
Helen Jarvis
}

\begin{abstract}
Introduction
A common challenge for cities and urban politics today is to restore a culture of liveability. What this entails in practice is heavily contested. Liveability is typically defined by the extent to which a place can attract and retain its population (homes, jobs, transport and the like); one with a good quality of life that makes provision for children and older people, clean air, green spaces, social and spiritual belonging, heritage and cultural sites. In many respects the concept of liveability reiterates parallel efforts to model urban development around ideas of "sustainable" and "harmonious" cities, "gender mainstreaming", UNICEF's "child-friendly city" and the WHO's "age-friendly city" global initiative (Buffel et al. 2012: 598). Fundamental to each place-based policy is an incomplete shift from "top-down" physical environmental development to "bottom-up governance", through resident participation. This chapter extends this transition to suggest that "a city for all" implies the right to "make and remake our cities and ourselves" through opportunities to appropriate urban space (such as ordinary streets) and to participate, individually, collectively and collaboratively, in decisionmaking surrounding the production of urban space (Harvey 2009: 315; Purcell 2003: 577).

According to the Philips Liveable Cities Think Tank (2011), for a city to be liveable it should combine resilience, inclusiveness and authenticity. But the qualities that make an area attractive to invest and live in are not always readily aligned with a progressive politics of social justice, or the freedom for all people to access urban public space equally. For many commentators, liveability conjures up the kind of relaxed, vibrant, walkable character which, in 'successful' high-growth cities, such as San Francisco and London, coincide with hostile forms of gentrification. This is where affluent population groups with high disposable income buy into and upgrade an area, pushing up living standards and costs that in turn displace vulnerable people and small businesses.

Ambiguity over the purpose of liveability, whether it is oriented to the inclusive 'good city' or the commercial attributes of a 'good life' for some, is due in part to a tendency for it to be measured by institutional actors and 'competitive' urban regeneration (Coe and Bunnell 2003; Tait and Jensen 2007). Mainstream research also tends to study large-scale 'flag-ship' macroeconomic development rather than the meso-scale of ordinary streets and neighbourhoods. This skewed attention neglects the informal grassroots social spaces that foster less tangible qualities of informal urbanism. Sophie Watson (2006: 5) captures a flavour of what is missed in her portrait of "magical urban encounters ... of buzzing intermingling ... [in] scruffy, unplanned and marginal public spaces"; describing from a visit to a local city farm in London "a space [that is] cut out of the railway sidings and abandoned land". This intermingling of different cultural groups and questions of connection and solidarity resonate with what Doreen Massey (2005) calls the 'thrown-togetherness' of disenfranchised people living together in marginal spaces (see also Amin 2004 on the politics of propinquity).
\end{abstract}


Whereas formal planning and urban design tend to measure social and material influence and impact in terms of profit and loss; in reality, how people inhabit a particular place involves many intangible qualities that are rooted in social connections which may not be measurable. The implication is that when formal planning fails to recognize or value this informal 'glue', it may inadvertently remove or destroy it, even when contriving to 'engineer' the qualities of liveability that allude the formal realm. As Scott (2012: 15) observes:

the more highly planned, regulated, and formal a social or economic order is, the more likely it is to be parasitic on informal processes that the formal scheme does not recognize and without which it could not continue to exist, informal processes that the formal order cannot alone create and maintain.

In the academic literature it is widely accepted that places are 'made' according to a vision that is variously imposed 'top-down' or that grows 'bottom-up' or indeed represents a hybrid of both formal planning and informal participation. More recently, academic debate highlights a trend of 'localism' that is evident on a number of intersecting geographic scales; as the currency of popular 'post-material' social movements seeking to reverse the decline of civic influence in local concerns; as a platform for issue-specific community-led development, such as locally defined housing; and as the substance and rhetoric of national planning and policy frameworks (Jarvis 2015a). This trend suggests broad political, cultural and practical alignment around the positive connotations of community participation. This is considered to summon forth new forms of citizenship that offer the potential for local residents to shape and influence neighbourhood development in socially progressive and sustainable ways. The expected outcome of citizen involvement is to validate the values of a shared identity, whether this is real or imagined.

Arguably, we need a new analytic approach that might think about local place-making influence more critically and, by the same token, to challenge what is deemed 'relevant' for planners and politicians to learn from. This is similar to the argument that Jennifer Robinson (2006) makes when she calls for an urban theory that accounts for a wider variety of 'ordinary' cities and, crucially, for analytical approaches that bridge between research on 'planning' in global or world cities and 'informality' in the small cities of 'less developed' countries (Bell and Jayne 2006: 5). This follows the many ways historically that towns, cities and urban places have come to be narrowly defined and 'measured' according to fixed categories, whether in relation to building density and scale, employment and wealth, transport and communication networks, social structures and governance, or tourism.

This chapter proposes a more nuanced urban analytic approach; one that pays greater attention to the intangible 'soft' architectures of everyday life; to recognize the importance of 'bottom-up' visions of development and alternative forms of building and managing local community assets (Jarvis 2015a). When citizens take over the management or ownership of public spaces or amenities in their neighbourhood, for instance, there is the potential to challenge mainstream development beyond the market and the state. A shift from 'top-down' to 'bottom-up' action can influence what counts (and what gets counted) and consequently the material changes that unfold and evolve in a given place. This in turn can challenge the 'metrics' underpinning conventional notions of liveability. The remainder of this chapter picks up this debate in the context of public space and civil society. This culminates in two case study examples of 'do-it-together' activism and community-led development: neighbours closing their street to allow their children to 'play out' in the UK (Box 28.1); and the Los Angeles Ecovillage project of grassroots activism (LAEV), USA (Box 28.2). 


\section{Public space and ordinary streets}

Much has been said in the literature about the end of public space. In contemporary cities, the public sphere is increasingly being seen to comprise dead public spaces, privatized shopping malls and gated communities, eroding the essence of city life (Low and Smith 2013; Paddison and Sharp 2007: 87). But significant gaps remain in our understanding of the fine-grained engagement with, and understanding of, particular public spaces by increasingly divided, diverse publics. Just thinking in terms of the complex and contradictory needs and concerns of young people, paid adult workers and older people; it is clear that efforts to create liveable cities for all ages are problematic (van Vliet 2011). The gaps in critical understanding and intervention are particularly apparent in prominent public spaces. Urban parks are still widely maintained, despite the pressures on local authorities to sell off playing fields. Yet these tend to be physically and culturally constructed around specific leisure activities, membership-based social groups and taxpayer interests. There are very few spaces or opportunities for ordinary citizens to collectively envision the public space of their imagination (for the seminal study of People's Park, California, see Mitchell 1995).

Public space functions on a continuum of ownership and access. For example, Clare Cooper Marcus (2002: 32) identifies five categories of outdoor space: private spaces owned by individuals (which are accessible only to them and their guests), corporate public spaces such as shopping centres (which are privately owned but open to the public), public spaces such as neighbourhood streets and parks (which are publicly owned and open to the public), shared spaces which are enclosed or gated (a community space owned by a group of residents which is usually accessible only to that group or their invited guests) and shared spaces which are open or porous (a collectively owned and managed landscape which allows the general public to wander through while at the same time providing a 'place-setting' for community life). These types of outdoor spaces can be expressed not only in terms of their legal ownership and associated governance (contrasting elected and non-elected representative bodies with collective, participatory decision-making) but also to the quality of social relations and encounters cultivated within them.

Since the nineteenth century, if not before, 'the street' has been regarded as a lively and contested public domain, the site of popular protest and political struggle. Yet, as a public space, the street is not especially accessible to people for multiple uses. In Britain, under the Highways Act of 1980, streets are provided and maintained solely for the passage of motorized traffic and any other activity can technically be described as an obstruction (Barrell and Whitehouse 2004: 262). This highlights the tensions that exist between streets for motorized transport and space for pedestrian activity. Contradictions are apparent today both in the desire for liveable streets and the material development of government-sponsored pedestrian-friendly commercial streets. As observed by Bell and Jayne (2006: 160) "the street itself can be either pedestrianised or given over to traffic, but streets remain highly regulated spaces where legal or social conventions delineate good behaviour".

Recent years have witnessed repeated attempts by campaigning organizations, artists and residents, to 'reclaim' and defend the 'local banal public spaces' of residential streets for pedestrian and community enjoyment (Grannis 1998; Paddison and Sharpe 2007). For example, the UK national charity Living Streets seeks to make streets "attractive and enjoyable spaces in which to live, work, shop and play safely". Founded in 1929 as the "Pedestrian Association', the 2001 name change reflects the move away from a reactive 'safety conscious' approach to traffic management towards a more proactive and holistic concern to cultivate 'sociability' and inclusion through everyday street social interactions. As we will see in Box 28.1, in the case study example of the Playing Out civic campaigning organization, ambitions to recreate the social life of the street and neighbourhood, as well as 'safe spaces' for children 
are often at odds with norms and cultures of parenting that prevent children's freedom to roam or engage in free-play. There are many other examples around the world of different motives and efforts to occupy the public spaces of the street. Probably the best known example is Occupy Wall Street which surfaced in New York before travelling the world as an idea for street reclaiming that captured the imagination as a spatial metaphor for challenging global social injustice (Penney and Dadas 2013).

Manuel Castells (2005) understands a culture of liveability in terms of the social-spatial connection of "local life, individuals, communes, and instrumental global flows through the sharing of public places" (2005: 60). Public space is understood as the key connector of human interaction and experience. Historically the form and use of public space has commanded considerable academic interest (Low 2000; Mitchell 2003). Lyn Lofland (1973: 34) points out that the pre-industrial city emphasized the multiplicity of uses to which public space could be put. The popular image is one of a bustling market-square in which traders and shoppers greet each other by name. This contrasts with the social isolation critics attribute to monotonous housing estates that lack local cultural identity and the drift to suburbanization that separates people from each other and from commercial districts and public amenities (Gehl and Svarre 2013). Post-war urban planning has been widely criticized for neglecting the humanistic significance of the neighbourhood landscape elements of ordinary streets, informal urbanism, the spaces between buildings and the transition or buffer spaces that often function as placesettings for community life. A notable exception is Jane Jacobs's 1961 classic 'anti-planning' thesis The Life and Death of Great American Cities (see also Sennett 1997) and, more recently, the counter-argument of Danish landscape architect Jan Gehl in his seminal text Life Between Buildings: Using Public Space (Gehl 2010).

Understanding liveability as a yearning for socio-spatial connection, it is constructive to draw on Sophie Watson's (2004: 210) notion of the street as a "space of democratic possibility". This emphasizes the co-constitutive functions of public space with public life or civil society. In the UK context, research undertaken by the Fabian Society highlights the crucial role of public green space, for instance, as providing 'places to be'

where we can come together, build relationships and reverse society's long-term journey towards individualism and isolation. These places are under threat. Central government funding for local authorities has fallen by around 40 per cent, leaving councils without the means to adequately maintain facilities or engage with local people.

(Wallis 2015: 2)

Sophie Watson argues that this social space of public life is not just about building social capital but also about creating and liberating spatial agency for imagining alternative possible futures. This justifies a turn away from looking at streets as fixed public spaces (auditing the quantity of benches or pedestrian access). Instead it suggests we need to understand and explore this landscape as a fluid dialogical space of inspiration and learning. The social learning may be to an extent scripted or engineered (as below in Box 28.1) or it may function through a more organic process of dreaming and enchantment (as below in Box 28.2, for the case study example of the LA Ecovillage, USA).

\section{Public life, civil society and intimate encounter}

Urban social theorist Henri Lefebvre argues that place-making is a social practice. The texture of everyday social settings and interactions operate largely at an unconscious level. This contrasts with the enduring faith that many planning practitioners and policy-makers hold in the power of physical design to change the social life of a community. In national policy terms, the late 1990s saw both Britain and the USA embark on an urban 'renaissance' which was 
replete with cultural and architectural motifs of village life inserted into the heart of the cosmopolitan city. This process appeared to capture a popular yearning for close-knit community affiliations, fondly remembered from snapshots of children playing in traffic-free streets in the 1950s and 1960s. A number of new social movements began to flourish; those associated with the 'post-material' values of slowness, simplicity, authenticity, community and conservation (movements spanning 'slow food', 'slow cities', 'transition towns', 'living streets' and 'voluntary simplicity'). At the same time, architects, planners and municipal leaders renewed their faith in the idea that positive attributes of community spirit could be cultivated by recreating 'traditional' urban residential neighbourhoods.

The social dimensions of public space introduced above are usefully explored with reference to what Georg Simmel has to say on the significance of co-present social interaction. Writing in the early twentieth century, his theorizing drew attention to a convivial scale of belonging that expanded upon the concept of Gemeinschaft (close-knit community) previously introduced by his contemporary Ferdinand Tönnies. Simmel recognized an affective 'being in togetherness' to Gemeinschaft, pointing to the universal occurrence in human development of a social pleasure in the physical company of others. He referred to this as Geselligkeit or the 'play-form' of association. This play-form introduced novelty and disruption to otherwise routine exchanges. Pleasurable mutuality could be further deepened through social aw areness and the questioning of taken-for-granted values (neighbours talking through differences in their upbringing, for instance). He observed that associations assumed greater depth when dialogue challenged taken for-granted norms and values. To Simmel (1903) the virtue of Geselligkeit is that engagement runs deep, beyond fleeting impressions. This recognizes the additional function of social learning as one of intersecting layers of understanding liveability.

Establishing a space of deep engagement, in a neighbourhood association or community cooperative, for instance, resonates with what Kittay (1999) and others have determined as 'love, care and solidarity'. It highlights concern not to romanticize public engagement without first asking who participates, for whose benefit (Jarvis 2015a). Activities such as attending public consultations, for instance, or promoting, campaigning and engaging in direct action inevitably involve unpaid 'work' as well as availability; just as someone can be 'present' but emotionally unavailable, the emotion-work of community associations can reproduce unequal divisions of labour or exclude certain population groups from the space of engagement. The emphasis placed at this scale of public life on 'social capital' and advanced inter-personal competencies also challenges the argument that community participation is sufficient as a mark of democratic development, "to encourage the inclusion of outsiders, to break down barriers created by wealth and privilege (or knowledge and motivation), or prevent those that are already better off and more dominant from flourishing at the expense of others" (Coote 2011: $85)$.

In practice, spatial and historical discontinuities highlight the paradox of 'localism' that is variously instrumental and involuntary. This is evident in the way that community groups and civic projects are increasingly expected in a climate of austerity to replace state welfare functions as reserve 'capacity' (Elwood 2004). In the Australian context, Argent (2005) describes this as a "neoliberal seduction". On the one hand the spatiality of localism is inherently attractive to rally popular support through "proximity, co-presence and reach". On the other hand, when public spending is cut, communities are often forced into driving local development as a kind of "mopping up" exercise (Argent 2005: 37). 


\section{From DIY to DIT}

Just as 'liveability' can appear to be both self-evident and abstract, definitions of public life are similarly contested. How we understand public life differs according to whether the service involved functions within or outside formal institutions - of politics, religion or education, for instance, where this broadly describes the work of 'networking' - to be known to a lot of people or connect one group of actors to another. The approach taken by urban design consultants Jan Gehl and Birgitte Svarre (2013: 2) views public life ethnographically in terms of "everything we can go out and observe happening" in public space; the mundane human behaviour "that takes place between buildings, to and from school, on balconies, seated, standing, walking ... far more than just street theatre and café life". A more autonomous, ideological approach views public life on a continuum of voluntary service from grassroots activism, community organizing, informal urban development to being a 'good neighbour'.

There is a long history to the idea of ordinary people organizing into groups and associations, acting on a voluntary basis to solve local problems. This form of direct action goes by a variety of names, including 'self-help' or 'do it yourself' DIY community action or community organizing. This chapter traces a subtle but significant transition from emphasis on individual action (the 'self' of DIY) to cooperative collaboration in 'do-it-together' DIT development. From the previous definitions of public life, an argument can be made for shifting research and debate away from preoccupation with the motives of individual activists finding common ground with others 'in resistance' (such as Occupy Wall Street) to draw attention to what it takes for people to 'change the world' in ordinary ways. This cultivation of a public life is fundamentally about local empowerment: it is less about "the transfer of decision-making power from 'influential' sectors to those previously disadvantaged or 'other' sections of society, but about these 'others' taking control and initiating different or 'alternative' spatial processes" such as community-led housing or the transfer of public assets into mutual ownership or management (Schneider and Till 2009: 100). A shift in focus from the individual actor to activist groups working together on a shared endeavour highlights the 'soft skills' of association and collaboration that have received limited attention in urban studies.

The literature on movements of 'street reclaiming' such as Occupy Wall Street typically define civic activism in terms of DIY democracy. This describes the horizontal processes of leadership and consensus whereby individuals are 'making themselves up as they go along' as producers and consumers combined. As Ratto and Boler (2014: 5) observe,

this self-creation can be seen in a positive light - for instance, as a reaction against the regulation of identity that can constitute the lived experience of a totalitarian government. However, it can also be understood as part of a hegemonic acceptance of the breaking apart and individualization of civil society.

It is therefore constructive to consider the emerging counter-trend of 'do-it-together' or DIT democracy. Richard Wolff (1998: 13) regards this as a socially progressive transition whereby creating your own direct environment with other people is the way to escape alienation and promote solidarity, respect and mutual support. If it is on the scale of a small village or a street, selforganization and direct action are the fundamentals of local action.

Further emphasis on renewed 'togetherness' is highlighted in two popular ethnographies that explore small self-organizing groups, including voluntary associations, church groups, clubs and civic societies (Hemming 2011; Sennett 2012). Both offer a timely counter-point to wellrehearsed concern for the decline in social trust and associational life over the past half century. Robert Putnam's (2000) thesis Bowling Alone epitomizes this concern. Rather than directly challenge accounts of increasing individualization and diminishing connections between people and between people and the places in which they live and work, Richard Sennett (2012) 
highlights the rich but fragile nature of these poorly understood associational relations. He argues that cooperation and collaboration need to be understood as craft skills that require people to understand and respond to one another in order to act together (Sennett 2012). In this sense the process of working together jointly is as significant as the goal or outcome: collaboration provides a catalyst of deeper levels of trust and cooperation, whether or not the group achieves their intended goal.

\section{Envisioning: a utopian method}

It is in order to highlight the place-based process of social learning and the 'play-form' of voluntary association that we turn now to a final linked concept: 'envisioning' liveability. This highlights an important distinction between the way that planners, politicians, policy-makers and practitioners typically conjure up an image of place through the development process, and how community groups imagine and realize what they want for their neighbourhood.

When asked to envision possibilities for a more equitable, just and ecologically sustainable urban future, David Harvey contends that most of what passes for city planning has been inspired by utopian modes of thought (Harvey 2000; MacLeod and Ward 2002: 153). Here, by contrast, envisioning is understood and conceived as a socio-cultural, socio-spatial project of shared endeavour as much as one that is rooted in a vision of a better alternative to mainstream options. This distinction is subtle but significant and it builds on an equally explicit distinction between an imagined utopia (destination) and utopian methods of thinking critically (journey) as motivation for transformation. In this sense, envisioning is about acting on a possibility to turn an idea into a reality where it is the process of this realization which is as transformational, if not more so, than the end result.

This discussion of concepts remains quite abstract. A more accessible way of illustrating what 'envisioning liveability' might look like in practice is suggested below; first in a poem, and then in two brief case study vignettes. Richard Delorenzi wrote the following poem while participating in a group activity for a community housing event in London on 29 June 2010. It was his inspiration for shared public space that was subsequently published in a Diggers and Dreamers handbook on the form of collaborative housing known as cohousing.

\section{We will build this place - and they will play (a cohousing project)}

My boy was born today, where will he play?

Will he play indoors on his own, all alone?

Will he play in the road, with the cars?

Will he play in the park, far away?

Let us get rid of the cars.

Let us know our neighbours.

Let us build a community together.

Let us talk in the streets, with no cars.

Let the children play.

Let the adults play.

Let the old people play. Let the children play.

(Richard Delorenzi, Community Land Trusts Conference, 2010, quoted from Bunker et al. 2011: 149. https://richarddelorenzi.wordpress.com/2012/04/16/we-will-build-this-place-and-they-willplay-a-co-housing-project/) 


\section{Box 28.1 Case study example: Playing Out - whose street? Campaigning for children's right to 'play out'}

Playing Out is a UK resident-led organization that echoes similar campaigns around the world intended to support people who want their children to be able to play freely in streets that are temporarily closed to traffic. The UK scheme suggests parallels with Donald Appleyard's advocacy of children's use of streets and sidewalks in Berkeley, California, in the 1960s and 1970s.

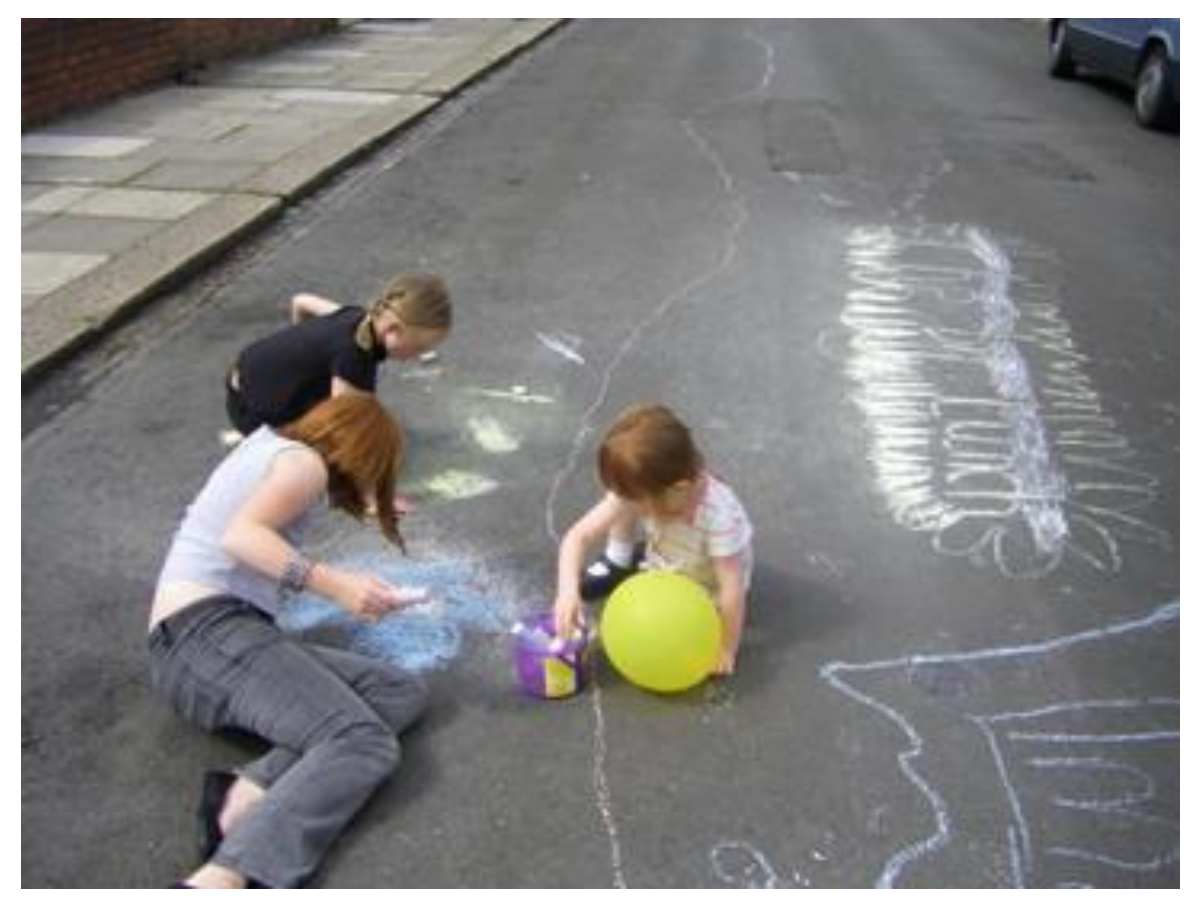

Figure 28.1 Let the children play: street closure for Big Lunch street party; children 'playing out', Newcastle upon Tyne, 2008

Source: photo: Helen Jarvis.

Playing Out began in Bristol on the modest scale of a single street: neighbouring mothers Alice Ferguson and Amy Rose shared their vision of making their residential street more 'liveable'. They recalled childhood memories of riding bikes and inventing games and lamented that, due to a high volume of traffic and lack of green spaces, their own children did not enjoy the same freedom. They had already set up a residents' association and this forum provided the necessary space to develop friendships, trust and local knowledge required to generate widespread support for regular temporary road closures. 


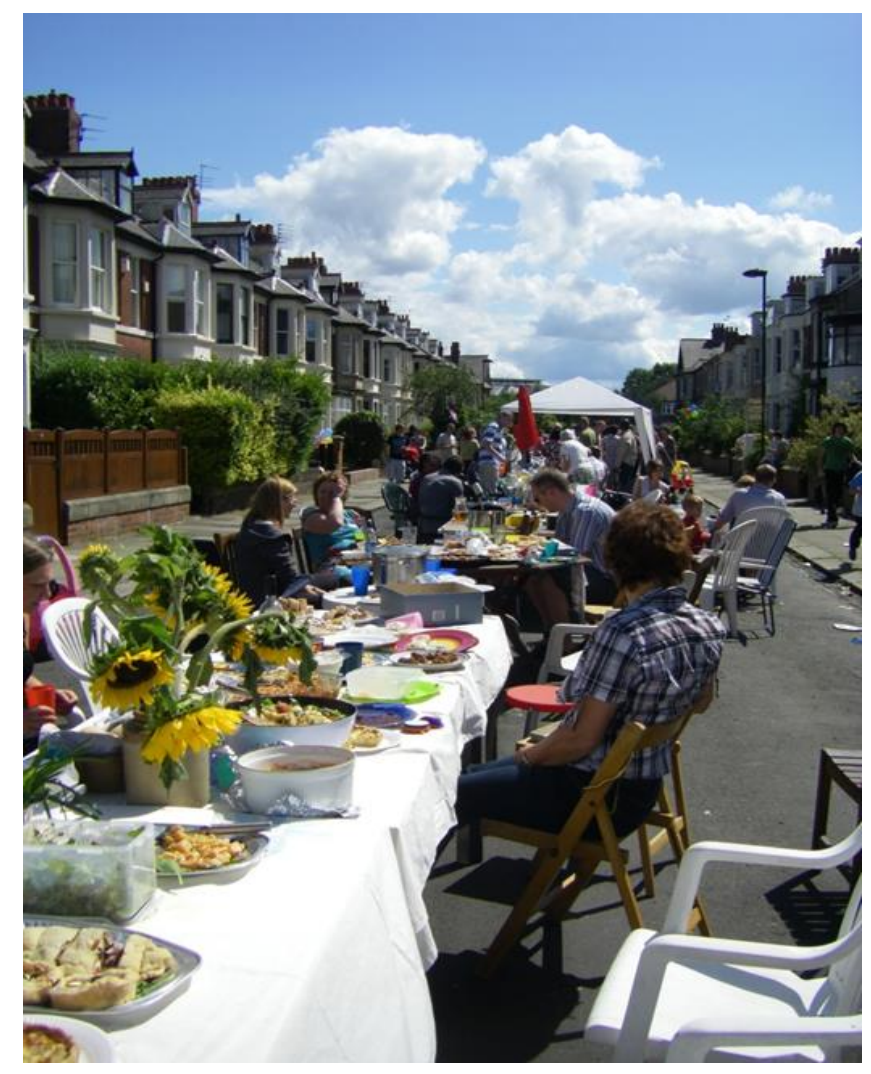

Figure 28.2 Let the adults play: street closure for Big Lunch street party, Newcastle upon Tyne, 2008

Source: photo: Helen Jarvis.

The first Playing Out session was organized to coincide with International Children's Day on 1 June 2009. It took several months to get permission to close the street from the relevant local authority because this required the full agreement of everyone living on the street. This necessarily involved a lot of talking and listening to each other's point of view on questions of whose street this was with respect to freedom and access. Residents were to be allowed car access during Playing Out sessions, escorted at walking speed by volunteer stewards, in effect creating a 'shared space' between cars and people. In the event, children of all ages played in the street together - on scooters and bikes, with balls and chalk or simply inventing games and talking together. Older residents and those less motivated initially to create child-friendly neighbourhoods learned to appreciate the 'buzz' that accompanied Playing Out sessions: there were impromptu picnics as outdoor seating provided a magnet for neighbours to spend time getting to know each other more deeply.

While Alice and Amy came up with the original proposal and galvanized other residents to share their enthusiasm, Playing Out would not have thrived and spread to other streets if it did not function as a 'do-it-together' project. It was not a trivial undertaking for neighbours to lift their gaze from their own household concerns to collaborate on a shared endeavour. But the hard work paid off. Residents on neighbouring streets wondered if they could also apply for temporary street closures and this way the idea travelled. Playing Out was formalized as a Community Interest Company in 2011, accompanied by the publication of a 'step-by-step' handbook and training sessions regularly delivered to resident groups around the UK (Ferguson and Rose 2010: 3-5).

Playing Out is a simple but effective example of how residents can act together to appropriate and 'domesticate' public space for new uses. It provides evidence of local people reclaiming access 
to the spaces in front of their homes, extending the reach of domestic space, metaphorically (if not literally) 'pulling down the fences' that typically contain and inhibit isolated, individual living arrangements. This temporary transformation is progressive because DIT planning introduces a space of deep engagement - what Simmel (1903) referred to as Geselligkeit.

\section{Box 28.2 Case study example: LA Ecovillage - a neighbourhood healing itself through cooperative development}

On my 2014 visit to the inner city site of the LA Ecovillage (LAEV) I was initially struck by the unplanned appearance of an unruly mix of street art, arid edible planting (the area was suffering from a serious drought), home-made street furniture (including a miniature lending library) and a brightly painted permeable road surface at the intersections of Bimini Place and White House. There were numerous hand-drawn signs urging drivers to 'slow down' while murals encouraged creative play. Accompanied on this occasion by my young daughter I regarded this playful environment as 'out of place' relative to the highly regulated and materially uniform street layout. It was as is if the kids had taken charge, casting aside the conservative interventions of parents, teachers and planning guidance. Yet, further investigation and a tour of the area revealed an extraordinarily well-orchestrated diffusion of civic organizing and local enterprise in and around this two-block neighbourhood.

The LAEV project is located on the northern edge of an area that was caught up and seriously damaged in the 1992 'riots' when civil disobedience followed the acquittal of police officers who were on trial for assaulting black man Rodney King captured in a videotape of his arrest. The neighbourhood is characterized by a mix of land uses including rental housing, commercial retail and light industrial zoning.

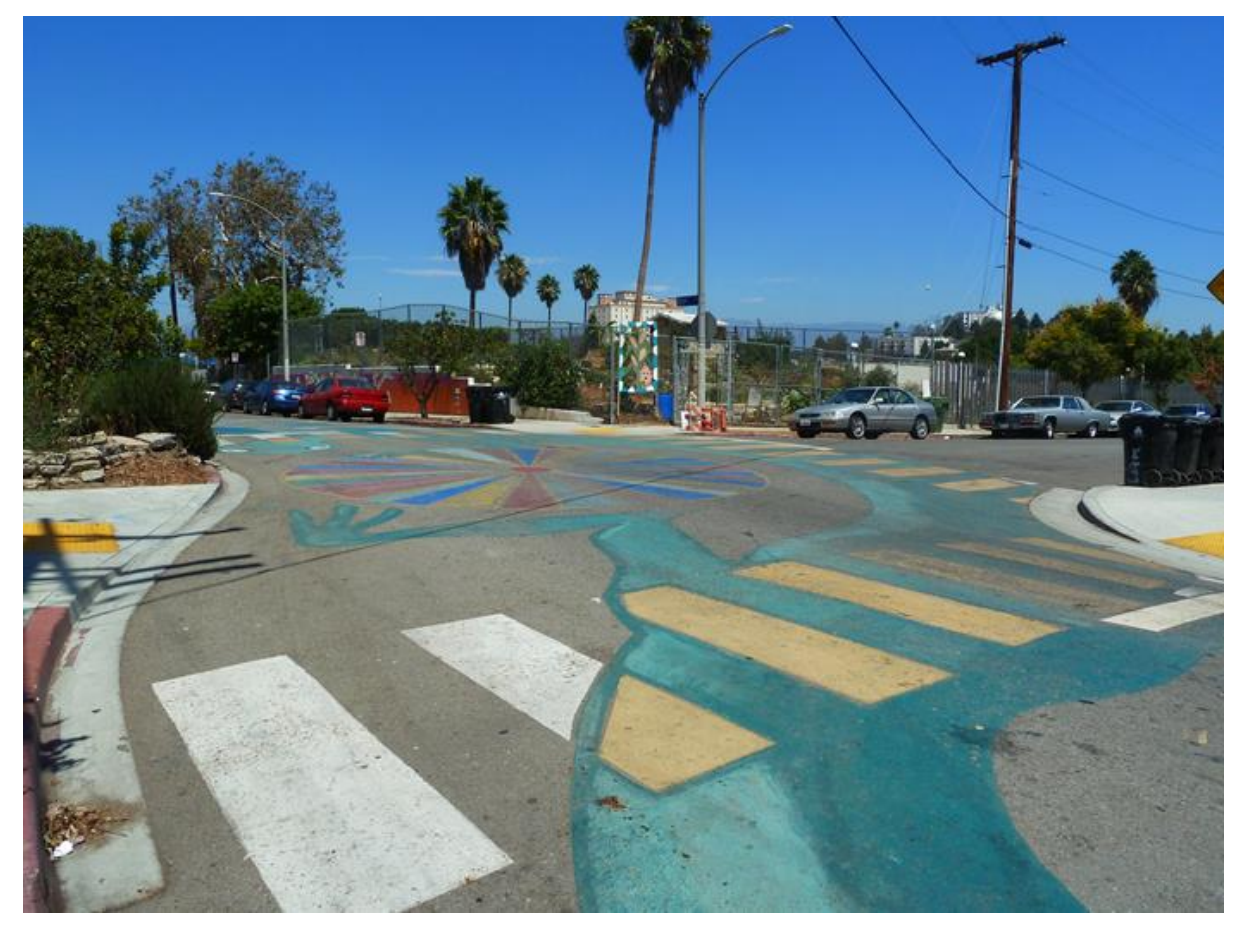

Figure 28.3 LA Ecovillage, view of White House Place Learning Garden

Source: photo: Helen Jarvis. 
The project started as an initiative of the Cooperative Resources and Services project (CRSP), a non-profit organization founded in 1980 by activist Lois Arkin. According to Boyer (2015: 330): around 1983 Arkin began to envision a 'neighbourhood of coops' that would allow individuals to access multiple services in the same space. In 1996 CRSP purchased the run-down Bimini Apartment Building with loans from friends and relatives, inheriting a number of sitting tenants, retrofitting it over time as a collectively self-governed cooperative based on ecological values.

Today, in addition to the forty-eight unit ecovillage, 'do it together' developments co-produced: the Bimini Slough Ecological Park; the White House Place Learning Garden; the Bicycle Kitchen (and the CicLAvia festival, a tradition borrowed from Bogota, Columbia that temporarily closes down stretches of downtown streets for cyclists and pedestrians which has grown into a citywide social event held five times per year), a café and 'bulk food buying cooperative' (plus annual 'Eco-Maya' festival celebrating Mayan heritage amongst LA residents), a curb-side 'lending library', a healing centre and a neighbourhood orchard 'offering fruits and nuts for everyone who passes by'.

(Boyer 2015: 332; Bimini Place 'Our History' Youth Care signage)

Each project demonstrates deep commitment to permanently affordable land and housing for lowerincome households. In this sense, do-it-together for-all protects this neighbourhood from gentrification for a select few.

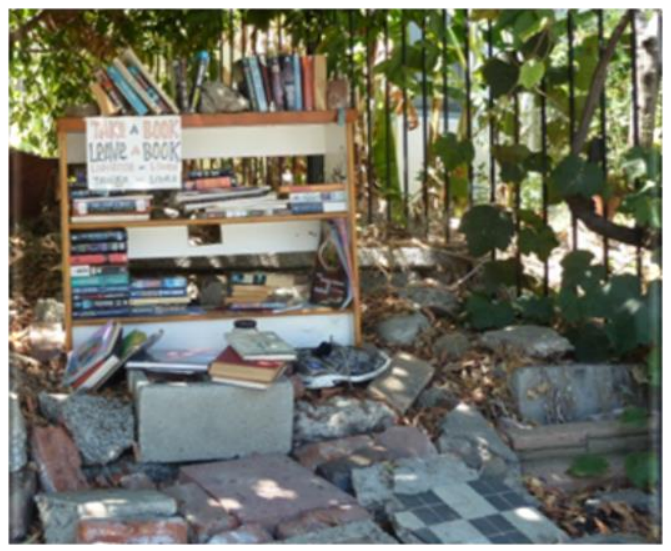

Figure 28.4 Open-air curb-side 'lending library' in front of LA Ecovillage

Source: photo: Helen Jarvis.

While Lois Arkin was particularly influential in the early envisioning process, from the outset she collaborated with activists sharing similar values. Over time the critical mass of LAEV comprised resident members (thirty-five 'intentional neighbours') working jointly with nonmember neighbours and enlightened non-profit practitioners representing the city at large. The sheer momentum and diffusion of DIT collaborative practice distinguishes this retrofitted neighbourhood development from other community-led housing projects that I have visited around the world (Jarvis 2015a). Loosely connected to a global ecovillage movement, where the intention is to model positive solutions to global ecological crises, LAEV functions as a source of inspiration and innovation, most notably the 'soft architecture' involved in assembling multiple local cooperative shared space economies. LAEV is illustrative of the scope of possibilities for DIY and DIT street-level transformation. 


\section{Concluding remarks}

By turning the attention to the banal and relatively unorganized spaces and practices of streets social interaction, this chapter finds evidence of local people, including children, claiming a place in the world; not through ownership but through shared endeavours and everyday habitual practice. Many of the terms and concepts used to describe this process of residential urban development, and what it takes for a neighbourhood to be 'liveable', invite simultaneously taken-for-granted and highly contested meanings. The simple term 'community' for instance is notoriously fuzzy and open-ended. It can refer to a neighbourhood or geographic association but it can also extend to common interests that transcend space and place, as with 'communities of interest'. Recognizing this problem and the way that politicians, planners and policy-makers often employ an imagined 'sense of community' and 'liveability' in rhetorical ways, this chapter calls for a new analytic approach.

The discussion and empirical examples highlight the significance of informal grassroots social spaces and DIT processes of local place-making. This is an important focus because we are witnessing a climate of local authority spending cuts in which many more public spaces and facilities are being transferred to management and delivery by volunteers. Discussion shows that people inhabit the neighbourhoods where they live and work in complex ways that involve many intangible qualities that are rooted in social connections - of inspiration, learning and wonder. These intangible qualities tend not to be recognized or valued by formal urban planning or policy-making.

Intangible qualities of association can be regarded as transformational because the active involvement of volunteers can empower them and the communities they are providing services for. At the same time, we must be careful not to romanticize the scale of the street, or the neighbourhood, as if participation at this local scale represents a distinct, homogenous whole, composed of people all speaking with a single voice. It is in order to challenge the shortcomings of narrow consultation that the analytic approach proposed here emphasizes the wider dialogical and evolving dynamics of envisioning.

\section{References}

Amin, A. (2004). Regions Unbound: Towards a New Politics of Place. Geografiska Annaler: Series B: Human Geography, 86(1), pp. 33-44.

Argent, N. (2005). The Neoliberal Seduction: Governing-at-a-Distance, Community Development and the Battle over Financial Services Provision in Australia. Geographical Research, 43(1), pp. 29-39.

Barrell, J. and Whitehouse, J. (2004). Home Zones - an Evolving Approach to Community Streets. Municipal Engineer, 157(4), pp. 257-265.

Bell, D. and Jayne, M., eds. (2006). Small Cities: Urban Experience Beyond the Metropolis. London: Routledge.

Boyer, R.H.W. (2015). Grassroots Innovation for Urban Sustainability: Comparing the Diffusion Pathways of Three Ecovillage Projects. Environment and Planning, 45 (2), pp. 320-337.

Buffel, T., Phillipson, C. and Scharf, T. (2012). Ageing in Urban Environments: Developing 'AgeFriendly' Cities. Critical Social Policy, 32(4), pp. 597-617.

Bunker, S., Coates, C., Field, M. and How, J., eds. (2011). Cohousing in Britain: A Diggers and Dreamers Review. London: D \& D Publications.

Castells, M. (2005). Space of Flows, Space of Places: Material for Theory of Urbanism in the Information Age. In: S. Bishwapriya, ed. Comparative Planning Cultures. London: Routledge, pp. $45-63$.

Coe, N.M. and Bunnell, T.G. (2003). Spatializing Knowledge Communities: Towards a Conceptualization of Transnational Innovation Networks. Global Networks, 3(4), pp. 437-456.

Cooper Marcus, C. (2002). Shared Outdoor Space and Community Life. Places, 15(2), pp. 32-41. 
Coote, A. (2011). Big Society and the New Austerity. In: M. Stott, ed. The Big Society Challenge. London: Keystone Development Trust Publications, pp. 82-95.

Elwood, S. (2004). Partnerships and Participation: Reconfiguring Urban Governance in Different State Contexts. Urban Geography, 25(8), pp. 755-770.

Ferguson, A. and Rose, A. (2010). How to Organise Playing out Sessions on Your Street - a Step-ByStep Manual. Bristol: Playing Out.

Gehl, J. (2010). Life Between Buildings: Using Public Space. Copenhagen: Danish Architectural Press.

Gehl, J. and Svarre, B. (2013). How to Study Public Life. Washington, DC: Island Press.

Grannis, R. (1998). The Importance of Trivial Streets: Residential Streets and Residential Segregation. American Journal of Sociology, 103(6), pp. 1530-1564.

Harvey, D. (2000). Spaces of Hope. Edinburgh: Edinburgh University Press.

Harvey, D. (2009). Social Justice and the City. Athens: University of Georgia Press.

Hemming, H. (2011). Together: How Small Groups Achieve Big Things. London: John Murray.

Jacobs, J. (1961). The Death and Life of Great American Cities. Harmondsworth: Penguin.

Jarvis, H. (2015a). Community-led Housing and 'Slow' Opposition to Corporate Development: Citizen Participation as Common Ground? Geography Compass, 9(4), pp. 202-213.

Jarvis, H. (2015b). Towards a Deeper Understanding of the Social Architecture of Co-housing: Evidence from the UK, USA and Australia. Urban Research and Practice, 8(1), pp. 93-105.

Kittay, E.F. (1999). Love's Labour. New York: Routledge.

Lofland, L.H. (1973). A World of Strangers: Order and Action in Urban Public Space. Prospect Heights, IL: Waveland Press.

Low, S. (2000). On the Plaza: The Politics of Public Space and Culture. Austin: University of Texas Press.

Low, S. and Smith, N., eds. (2013). The Politics of Public Space. New York: Routledge.

MacLeod, G. and Ward, K. (2002). Spaces of Utopia and Dystopia: Landscaping the Contemporary City. Geografiska Annaler: Series B, Human Geography, 84(3-4), pp. 153-170.

Massey, D. (2005). For Space. London: Sage.

Mitchell, D. (1995). The End of Public Space? People's Park, Definitions of the Public, and Democracy. Annals of the Association of American Geographers, 85(1), pp. 108-133.

Mitchell, D. (2003). The Right to the City: Social Justice and the Fight for Public Space. New York: Guilford Press.

Paddison, R. and Sharp, J. (2007). Questioning the End of Public Space: Reclaiming Control of Local and Banal Spaces. Scottish Geography Journal, 123(2), pp. 87-106.

Penney, J. and Dadas, C. (2013). (Re) Tweeting in the Service of Protest: Digital Composition and Circulation in the Occupy Wall Street Movement. New Media \& Society, 16(1), pp. 74-90.

Philips Liveable Cities Think Tank (2011). Liveable Cities-poster. http://thisbigcity.net/infographicwhat-makes-a-liveable-city/ [accessed 20 April 2017].

Playing Out. www.playingout.net [accessed 3 November 2015].

Purcell, M. (2003). Citizenship and the Right to the Global City: Reimagining the Capitalist Working Order. International Journal of Urban and Regional Research, 27(3), pp. 564-590.

Putnam, R.D. (2000). Bowling Alone: The Collapse and Revival of American Communities. New York: Simon \& Schuster.

Ratto, M. and Boler, M. (2014). DIY Citizenship: Critical Making and Social Media. Cambridge, MA: MIT Press.

Robinson, J. (2006). Ordinary Cities: Between Modernity and Development. London: Routledge.

Schneider, T. and Till, J. (2009). Beyond Discourse: Notes on Spatial Agency. Footprint. Delft Architectural Theory Journal, 4 (Spring), pp. 97-111.

Scott, J.C. (2012). Two Cheers for Anarchism: Six Easy Pieces on Autonomy, Dignity, and Meaningful Work and Play. New York: Princeton University Press.

Sennett, R. (1997). The Uses of Disorder: Personal Identity and City Life. New York and London: W.W. Norton.

Sennett, R. (2012). Together: The Rituals, Pleasures and Politics of Co-operation. London: Allen Lane.

Simmel, G. (1903). The Metropolis and Mental Life. Individuality and Social Forms. In: D.N. Levine, ed. (1971), Selected Writings. Chicago: University of Chicago Press, pp. 324-339. 
Tait, M. and Jensen, O.B. (2007). Travelling Ideas, Power and Place: The Cases of Urban Villages and Business Improvement Districts. International Planning Studies, 12(2), pp. 107-127.

Van Vliet, W. (2011). Intergenerational Cities: A Framework for Policies and Programs. Journal of Intergenerational Relationships, 9(4), pp. 348-365. 